\title{
Wstęp: wojna, obraz, propaganda
}

Nikogo nie trzeba przekonywać, że plakat wciąż stanowi ważne narzędzie komunikacji wykorzystywane przez rozmaite siły polityczne, militarne czy gospodarcze. Choć jest to medium jednokierunkowego przekazu, to jednak potęga jego oddziaływania, mierzona choćby stopniem rozpoznawalności przez odbiorców treści posterów, jest bezdyskusyjna. Pokolenia, które doświadczyły czasów realnego socjalizmu w Polsce, z reguły nie mają problemów z przypomnieniem sobie co najmniej kilku plakatów propagandowych i haseł na nich zawartych, podczas gdy wiele innych elementów minionej rzeczywistości rozmyło się i zatarło w zbiorowej pamięci. Dziś wyrazem ich nieprzemijającej popularności (a nawet swoistej mody) są na przykład reprinty i kalendarze zawierające przedruki starych posterów, stające się częścią dekoracji przestrzeni zarówno publicznych, jak i prywatnych. Często też dawne postery wykorzystywane są w działaniach promocyjnych i marketingowych. Motywy oraz hasła z plakatów nieustannie cyrkulują $\mathrm{w}$ naszej ikonosferze, są kopiowane, cytowane, a także przekształcane.

Pojawia się zatem pytanie: co leży u źródła siły plakatu? Odpowiedź wydaje się związana ze specyfiką przekazu umieszczonego na posterach. Jest on prosty, zazwyczaj jednoznaczny i eksponowany w przestrzeni publicznej. Nie bez znaczenia jest też niekiedy kontrowersyjność i ultymatywność zawartych w nim treści, które siłą symboli do czegoś przekonuja, zniechęcają lub utrzymują w określonym postanowieniu.

Monografia, którą oddajemy do Państwa rąk stanowi kontynuację socjologicznej refleksji nad plakatem propagandowym, rozpoczętej w książce Socjologia wizualna w praktyce. Plakat jako narzędzie propagandy wojennej, wydanej w roku 2011. Perspektywa badań nad wizualnościa, jaką przyjęliśmy w poprzednim tomie poświęconym plakatom wojennym, jest tutaj 
kontynuowana i rozwijana. Jesteśmy przekonani, że socjologiczna analiza posterów może być równie skutecznie wykorzystana w odniesieniu do materiału historycznego, pochodzącego z mniej lub bardziej odległej przeszłości, jak i do badania współczesnych komunikatów wizualnych. Choć zmieniły się okoliczności geopolityczne i nastąpiło przesunięcie biegunów i linii demarkacyjnych pomiędzy mocarstwami, plakat nadal święci triumfy, skutecznie opierając się zdecydowanie bardziej nowoczesnym postaciom przekazu opartym na interaktywnej formie komunikacji nadawcy i odbiorcy. W zasadzie można uznać, że poster został „wchłonięty" i zaadaptowany przez nowoczesne media, w związku z czym, choć rzadziej pojawia się na ścianach, słupach i innych elementach przestrzeni publicznej, wrósł w cyberprzestrzeń na trwałe znajdując tam miejsce dla siebie. Tendencja ta świadczy niewątpliwie o uniwersalności tego typu przekazu, który ze względu na swoją specyfikę zmienia jedynie lokalizację, nie zaś formę. Plakat, niezależnie od szerokości geograficznej, ustroju politycznego oraz intencji nadawcy, nadal jest istotnym nośnikiem idei, narzędziem manipulacji i perswazji. Choć w porównaniu z czasami działań wojennych mniej jest w teraźniejszym plakacie nawoływań do nienawiści i treści ksenofobicznych, na korzyść propagowania interesu określonej grupy społecznej, to nadal stanowi on częste narzędzie w walce o „rząd dusz”. Przykład stanowić mogą wszelkiego rodzaju ruchy społeczne o charakterze ortodoksyjnym, których, nierzadko ekstremistyczne, stanowiska odzwierciedlane są $\mathrm{w}$ wizualnych reprezentacjach. Ich obecność i wzrastająca popularność, zwłaszcza w dobie kryzysu gospodarczego, składa się na współczesny pejzaż debaty społecznej, wyznaczając nie tylko jej obszar, lecz także poziom, a przy tym skłania do poszukiwań historycznych analogii. Elementy dyskursów publicznych, obecne w wielu państwach i obszarach kulturowych, wyrażone poprzez plakaty, stały się zasadniczą treścią niniejszej pozycji. Zawiera ona analizy plakatów pochodzących z kilku dekad, poczynając od II wojny światowej, poprzez rzeczywistość zimnowojenną aż do czasów nam współczesnych, w których plakat nie utracił nic ze swej mocy i popularności.

Książka zawiera osiem tekstów. Pierwsze cztery stanowią kontynuację tematów podejmowanych przez autorów w pierwszym tomie, poświęconym wojennym posterom. Ich wspólnym mianownikiem jest tematyczne zakorzenienie w okresie II wojny światowej lub w zimnowojennej rzeczywistości lat 50. i 60. wieku XX.

Tom otwiera studium Mai Brzozowskiej-Brywczyńskiej, w którym analizie poddana została brytyjska kampania propagandowa Dig for Vic- 
tory! z okresu II wojny światowej. Autorka koncentruje się na wewnętrznym, „domowym” froncie walki, gdzie kwestie żywnościowe były równie ważne, jak problemy uruchomienia produkcji militarnej czy rekrutacja żołnierzy. Racjonowanie żywność stało się koniecznościa, podobnie jak zmiana kulinarnych nawyków Brytyjczyków. Celem kampanii było między innymi mobilizowanie społeczeństwa do przekształcenia ogródków, parków i skwerów w warzywne działki, co znalazło swoje odzwierciedlenie także na plakatach. Kluczowymi, „strategicznymi” warzywami stały się ziemniaki i marchewki, co miało zaskakujące konsekwencje także w kontekście działań militarnych oraz strategii dezinformowania wroga. Drugi z tekstów, pt. Społeczne reprezentacje chorób wenerycznych na plakatach z okresu I i II wojny światowej, autorstwa Marcina Kotrasa, przybliża kwestie propagandy zdrowotnej z okresu I i II wojny światowej na przykładzie kampanii zwróconych przeciw chorobom wenerycznym. Autor ukazuje rozmaite społeczne reprezentacje tego rodzaju zakażeń, które w czasie trwania obu konfliktów przybierały prawdziwie masowy charakter. Szacunkowo problem dotyczył około dziesięciu procent żołnierzy po każdej stronie linii frontu. Wymagało to zatem zdecydowanych działań propagandowych i profilaktycznych. Autor, stosując metodę kodowania otwartego, przeanalizował ponad 50 plakatów. Wykorzystał przy tym elementy społecznej teorii reprezentacji, odczytując kolejne postery poszukiwał struktur narracyjnych zakorzenionych w kulturze danych społeczeństw.

Kolejne studium, Religijne odniesienia w propagandzie wojennej. Analiza zjawiska, skupia się na ukazaniu religijnych odniesień $\mathrm{w}$ wizualnej propagandzie wojennej. Jego autor Łukasz Kutyło swoim zainteresowaniem objął zarówno plakaty, jak i kartki pocztowe z okresu wojen światowych, wojny domowej w Rosji oraz wojny polsko-bolszewickiej. Kluczowe pytanie, na jakie autor tekstu poszukiwał odpowiedzi, dotyczyło tego, w jaki sposób instrumentalizowana jest religia na użytek wizualnych przekazów propagandowych? Inne pytanie dotyczyło tego, jak chrześcijaństwo, religia miłości i pokoju, mogło być wykorzystywane przez twórców propagandy w celach czysto militarnych? W tekście ukazano rozmaite strategie zastosowania odniesień religijnych, między innymi poprzez odwołania do wizerunków świętych, Jezusa, szatana, smoka itd.

Tekst Piotra Chomczyńskiego ¡Viva la Revolución! Rewolucja kubańska 1956-1959 i jej konsekwencje w rzeczywistości zimnowojennej. Socjologiczna analiza plakatów kubańskich, zamyka pierwszą część książki. Stanowi on próbę spojrzenia poprzez pryzmat działań propagandowych na niewielki kraj z regionu Morza Karaibskiego, który pół wieku temu był na ustach całej 
opinii publicznej. $\mathrm{W}$ rozdziale zawarte są rozważania na temat plakatów ery Fidela Castro i jego ekipy, stanowiących punkt wyjścia szerszych konstatacji na temat wydarzeń, które nawet realiści postrzegali jako możliwy początek wojny atomowej. Choć tekst koncentruje się na propagandzie kubańskiej, to jednak definiuje linię sporu pomiędzy Kubą jako samozwańczym wyrazicielem interesów krajów Ameryki Południowej i Związkiem Radzieckim wraz z jego sojusznikami a Stanami Zjednoczonymi i ich poplecznikami. Analiza ich treści wykonana została z użyciem metodologii teorii ugruntowanej, która pozwoliła na wygenerowanie kategorii analitycznych, stanowiących zasadniczą strukturę tekstu.

Druga część książki zawiera cztery kolejne rozprawy, które w mniejszym lub większym stopniu odnoszą się do czasów współczesnych. Pierwsza z nich, pt. "I want you..." $i$ "We can do it" - szkic do analizy kulturowych transformacji plakatów wojennych, autorstwa Tomasza Ferenca, stanowi próbę ukazania kulturowych transformacji plakatów wojennych z I i II wojny światowej. Punktem wyjścia staje się tu analiza „klasycznych" motywów plakatów, ukazanie ich genezy oraz świadectw ich recepcji w epoce, w której powstały. Jednak zasadnicza część tekstu skupia się na opisie współczesnych przekształceń tudzież zapożyczeń tych motywów dokonywanych w różnych celach. Autor wyodrębnił trzy kategorie transformacji posterów, dokonywanych w celach ideologicznych, komercyjnych oraz subwersywnych.

Analizie amerykańskich plakatów filmowych z różnych okresów historycznych poświęcony jest tekst Urszuli Jareckiej pt. Propaganda postaw prowojennych: plakaty filmu wojennego. Każdego roku w repertuarze kin na całym świecie pojawiają się setki obrazów, które ukazują historyczne i współczesne zmagania militarne. Film, poza czysto komercyjnym celem, dla którego został stworzony, jest nośnikiem ideologii; promuje określone postawy i wartości, które „powinien” przyjąć jako własne widz zasiadający w kinie. Plakat, towarzyszący wejściu na ekran nowego produktu z „fabryki snów", w syntetycznej formie anonsuje treści, a przede wszystkim przesłanie, jakie ów produkt niesie. Jest swoistym signum temporis postaw i „stanu ducha” czasów, w jakich film powstawał i był upowszechniany. Autorka sięga jednak dalej, poza czysto historyczny kontekst. Stawia między innymi pytania o „życie plakatu” wojennego w czasie odległym od jego pierwotnego użycia. Ukazuje, jak dawne obrazy funkcjonują w nowej rzeczywistości; jak są wykorzystywane do promowania postaw i wartości pożądanych w zupełnie innym momencie historycznym. 
Kolejny szkic także nawiązuje do tematyki filmowej, jednak tym razem obszarem badania stała się treść samego dzieła. Materiałem, na którym oparł swoje rozważania Sebastian Latocha, stał się film dokumentalny Marii Zmarz-Kochanowicz Kocham Polskę. Film ten staje się pretekstem do badania dyskursu wojny; języka oraz rozmaitych wizualnych manifestacji charakterystycznych dla formacji znanej jako Młodzież Wszechpolska. Autor zwraca uwagę i koncentruje się na osobliwości propagandy stosowanej przez MW. Jej centralnym punktem stało się właśnie pojęcie wojny, konfliktu, konfrontacji kultur. Metaforyczne posługiwanie się terminem „wojna”, staje się, co wykazuje autor tekstu, dla Wszechpolaków sposobem na opisywanie otaczającej ich rzeczywistości, a dalej rzeczywistością samą w sobie. Swoje analizy Latocha popiera kadrami z filmu Marii Zmarz-Kochanowicz, ukazując, w jak niesamowity sposób retoryka werbalna splata się w przypadku tej formacji ze środkami ekspresji wizualnej.

Zamykający niniejszy tom, tekst autorstwa Waldemara Dymarczyka pt. „Faszyzm?!? My jesteśmy gorsi!!!” Wspótczesny polski plakat nacjonalistyczny, to analiza obszernego zbioru posterów i innych graficznych reprezentacji („wlepek”, bannerów), służących promocji postaw, wartości i programów organizacji o nacjonalistycznej proweniencji. Są to obrazowania i deklaracje ideologiczne, które zaistniały w ostatnim czasie i nierzadko zyskały szeroki oddźwięk, pomimo (a może dzięki temu) że zostały wytworzone poza "oficjalnym nurtem" i bez mecenatu instytucji państwa demokratycznego oraz wbrew powszechnie obowiązujące$\mathrm{mu}$ konsensusowi. Warto $\mathrm{w}$ tym miejscu postawić pytanie, czy sam fakt bycia kontestatorem istniejącego porządku, co było charakterystyczne w minionym systemie, „powinien” ewokować pozytywne postawy wobec tego rodzaju "produktów”? Czytelnik odnajdzie w tekście jasną odpowiedź. Autor pragnąc uniknąć (o ile to w ogóle możliwe i wskazane) osobistych uprzedzeń i animozji, zastosował rygorystycznie reguły metodologii teorii ugruntowanej zaadaptowane na potrzeby analizy danych wizualnych. Nie znaczy to, rzecz jasna, że badacz nie wyraził implicite i explicite swojego stosunku do treści i formy współczesnych plakatów nacjonalistycznych.

Mamy wielką nadzieję, że drugi tom poświęcony plakatom wojennym uzupełnia i poszerza treści zawarte w pierwszej książce. Autorzy tekstów wskazali szereg nieeksplorowanych do tej pory zagadnień w obszarze rodzimej socjologii, proponując kilka ujęć teoretyczno-metodologicznych. Jednocześnie starali się wykazać konieczność badania współczesnych form propagandy o charakterze militarnym. Retoryka wojenna wraz z jej do- 
słownością, agresywnością, polaryzowaniem opinii i dzieleniem na „swoich" i „obcych" wciąż znajduje społecznie podatny grunt (zyskuje nawet coraz większą popularność). Dlatego przyjmujemy, że istnieje konieczność obserwowania, opisywania i analizowania tego rodzaju komunikatów zarówno w ich dawnych formach, jak i we współczesnych transformacjach. Kilkaset zreprodukowanych i przeanalizowanych w książce plakatów ma służyć lepszemu zrozumieniu zjawiska, jakim jest wizualna propaganda o charakterze wojennym.

Tomasz Ferenc, Waldemar Dymarczyk, Piotr Chomczyński 